\title{
How Effective is the Registration of Sales?
}

\author{
Hana Zídková - Jana Tepperová*
}

\begin{abstract}
:
The registration of sales is a topical issue of the tax policy and one of the recent measures against the shadow economy and tax evasion introduced in the Czech Republic. After its implementation, first evaluations of the impact on tax revenues are being provided. Within this paper, we discuss the methodology used to provide estimates of the increase in tax revenues based on the national accounts data, estimate the increase in VAT revenues for restaurant services and compare it with previous estimates. We provide three different estimates according to the assumed proportion of VAT non-tax payers based on national accounts data. According to our results, VAT revenues would increase by approx. 2.5 bill. CZK when all restaurants become VAT payers or by approximately 1 bill. CZK if only $8 \%$ of restaurants remain VAT non-payers. If the proportion of VAT non-payers does not change after the registration of sales, the VAT revenues would decrease by 0.45 bill. CZK due to the reduction of the tax rate.
\end{abstract}

Key words: Registration of sales; Shadow economy; Concealed revenues; Estimates.

JEL classification: $\mathrm{H} 2$.

\section{Introduction}

Tax evasion and avoidance is a current topical issue in almost all countries across the globe, and governments are taking measures to combat it. Many scholars research the factors of tax evasion from different perspectives to advise the policy makers about the best approach in fighting against this phenomenon. Well known paper of Allingham and Sandmo (1972) explores the relationship between the willingness of an individual to evade taxes and the probability of detection of this behaviour by financial officers together with the severity of penalisation. Other studies elaborate on demographical and personal traits that relate to the tendency to avoid paying taxes. For example, a negative relationship between age and the propensity to tax evasion was discovered by various authors (Daude, Gutiérrez, Melguizo, 2013, Hug and Sporri (2011), Gaviria (2008). Less explicit results were found regarding the connection between education or level of income of the

\footnotetext{
Hana Zídková; University of Economics, Prague, Faculty of Accounting and Finance, Department of Public Finance, W. Churchill Sq. 4, 13067 Prague, Czech Republic, <hana.zidkova@vse.cz>. Jana Tepperová; University of Economics, Prague, Faculty of Accounting and Finance, Department of Public Finance, W. Churchill Sq. 4, 13067 Prague, Czech Republic, $<$ jana.tepperova@vse.cz>.

The article is processed as an output of a research project of the Faculty of Finance and Accounting, University of Economics, Prague, which is carried out within the institutional support of University of Economics, Prague IP 100040.
} 
taxpayers (Torgler, 2012, Alm, Martinez-Vasquez and Torgler, 2006). Other authors examined the impact of the institutional variables: perception of corruption and satisfaction of people with the public administration including public spendings on the volume of tax evasion within the country (Bird et al, 2004). Yet another direction of research focused on psychological elements present between tax administration and taxpayers (Frey, 2003).

All these findings can certainly help in setting up a suitable tax policy and administration. Reflecting the significant factors influencing tax evasion could make new legislative measures in the field of taxation and enforcement of tax collection much more efficient; not to speak of possible improvement in communication between taxpayers and financial officers. The so-called client approach belongs indisputably among current trends in many countries and was also recommended by several studies (Hofmann et al, 2008).

In spite of all these possibilities mentioned above, one of the most effective methods of suppressing tax evasion could be minimising the opportunity to avoid taxes. The most common ways that tax liabilities are underreported are suppressing sales, falsifying suppliers' invoices or otherwise tampering deductible expenses, and hiding from registration to taxes (Tait, 1988). Many countries have implemented various tools using advanced technologies to tackle these types of evasion (OECD, 2017). For suppressing sales, the most common tools used are cash registers in various forms either connected directly to financial authorities' servers or offline, but equipped with anti-tampering software that blocks the possibility to change the sales data retrospectively. Not only are taxpayers omitting cash sales, but also those paid by bank transfers. Tampering software named phantom-ware or zappers that falsify the accounting records enables this.

Fiscalization of cash sales (and sometimes digital sales too) is implemented in Austria, the Slovak Republic, Hungary, Croatia, Sweden, and Belgium, for example. Obligatory usage of security tools that disallow changing digital records on cash registers or computer-based tills is planned in France, Germany, Greece and Finland from 2018. So called quality mark that would certify the cash registers for storing and processing data reliably is encouraged in the Netherlands (OECD, 2017). The taxpayers implementing those quality marks would gain beneficial treatment from the tax authorities in return. Therefore, it is not surprising that registration of sales was also introduced in the Czech Republic. Since 2016, it is the number one topic, both economically and politically, on the Czech tax scene.

First numbers are being discussed due to post implementation experiences. The financial authority argues that the registration of sales has already proven to be an effective measure of increasing tax revenues (Financial administration, 2017a; Hrstková, 2017). Mainly small businesses oppose disproportionate administration 
and distrust (e.g.: ČTK, 2017). Furthermore, the closed business cases are being discussed in addition to the volumes of tax revenues (e.g.: Ťopek, 2017).

The novelty of the registration of sales is obligatory evidence of each cash payment, which has not been required before. A receipt with unique registration number generated by the tax administration server must be issued for each costumer. This requires continuous connection of the cash registers and robust IT system. This system shall reveal hidden (untaxed) income and provide data to tax administration for more effective tax audits.

Registration of sale has not been fully implemented yet as its gradual implementation is planned in four steps. First, businesses (entrepreneurs and businesses in field of accommodation and food services) joined the registration of sales on December, 1st, 2016. The second phase of implementation (retail trade and wholesale) took place on March, 1st, 2017. Third and fourth phases are scheduled for March and June, 2018. After the start of the second phase (to March, 1st) more than 114,000 subjects have registered (Financial Administration, 2017b). This is less than the original assumption of approx. 240,000 subjects (MFCR, 2015).

The Czech model for registration of sales was inspired to a great extent by the Croatian fiscalization reform (MFCR, 2015). Shortly after the implementation, Croatian studies suggested and increase in reported taxable revenues from 4,8 (for lawyers) to $40 \%$ (for caterers) in comparison to 2012 without the registration of sales and 2013 after the registration of sales was implemented. A positive result of fiscalization: the encouragement of discussion about the need for fair and transparent business, was mentioned, and the combat of the grey economy was considered as one of the highest advantage. (Tot, Detelj, 2014) This is also why a significant increase in tax revenues after implementing the registration of sales in the Czech Republic was assumed. However, it has already been argued that the Czech Republic comes out better in comparison with Croatia in extent of shadow economy, thus, a similar increase cannot be expected (Kovanda, 2015a, 2015b).

The aim of this paper is to discuss the methodology to estimate the increase of VAT revenues after the registration of sales based on national accounts data, provide estimates for restaurant services, and to compare the results with the estimates provided by the Ministry of Finance prior to the implementation of the new legislation. 


\section{Data and Methodology}

The registration of sales is aimed at suppressing both the income tax and VAT evasion that arises from non-reporting all cash revenues. Nevertheless, at this stage of our research, we decided to focus on potential VAT revenues instead of income tax and social security contributions. This is because the potential increase of the latter revenues is far more difficult to estimate due to complicated calculations of tax base using various tax deductions.

Different sets of data can be used to estimate the additional VAT revenues stemming from the registration of sales applied to a certain field of the industry. The data from the VAT returns submitted to the financial administrators are optimal, but national accounts data, specifically the supply and use tables, can also be taken as base for calculations. As the VAT returns data that are confidential and not available to us, we work with the statistical data from the national accounts.

\subsection{Theoretical Tax Base}

Theoretically, the tax base for VAT revenues collected by public budgets is the final consumption of mainly households and of public institutions and non-profit organizations. A part of the "macro-economic" tax base for VAT is also created by the intermediate consumption and capital formation by the companies and other entities not claiming the input tax deduction. The VAT they paid for in their purchases remains in the public budgets equally as the VAT paid by the final consumers.

We estimate the additional VAT revenues will be gained from the registration of sales in the restaurant services only from the final consumption. We disregard the potential changes in intermediate consumption and capital formation for the following reasons. First, capital formation is not applicable for restaurant services. Second, we suppose that the intermediate consumption of restaurant services is well documented as it creates the costs of the companies or individuals purchasing those services for their economic activities. We recognize that some part of intermediate consumption could have been concealed before the registration of sales. These were the purchases of restaurants that did not report their sales to final consumers and adjusted their accounting by not recording the purchases either. However, if such intermediate consumption becomes official, the suppliers will pay for the output VAT after the registration of sales, and, on the other hand, the input VAT will be claimed by the restaurants who purchase it. This would not mean any additional revenues for the public budgets. 


\subsection{Hidden Sales}

It should be noted that the final consumption published by the Statistical Office in the national accounts comprises an estimated share of the concealed sales. This approach is required by the European System of National and regional Accounts (ESA, 2010). We assume that the tax administrators will collect additional VAT revenues in 2017 thanks to reporting all sales for final consumption in their VAT returns. Registration of all sales (including those previously hidden) should, in an ideal situation, equalize the VAT base with the final consumption.

There are acknowledged studies of Friedrich Schneider on shadow economy (Schneider, 2007) regularly updated (Schneider, 2015). However, for our analysis, we used the data published by the Czech Statistical Office (further "CSO") since they are distinguished for individual industries. The CSO estimates the concealed sales in the field of hotel industry and restaurant services at $19.56 \%$ (CSO, 2012). We assume the same share of hidden sales in 2015. Therefore, we deduct this proportion from the 2015 final consumption in the national accounts to estimate the volume of restaurant services reported to the financial authorities and compute the VAT on restaurant services collected in 2015. As the hidden sales are already included in total consumption in the national accounts, we calculate the volume of hidden sales ("HS") from the total consumption by multiplying the reported number by a coefficient equal to $16.36 \%$ (19.56 / (119.56). These estimated (2015) revenues are then compared to VAT revenues to be collected after the registration of sales in 2017 as Formula 1 explains further in the text.

\subsection{Limits of the Methodology}

Before the actual calculation of the potential increase of VAT revenues, it should be noted that the method has its limits. Firstly, the weighted average VAT rate ("WAVR") applicable on restaurant services in 2015 used in our model calculation is $21 \%$. However, the restaurant sales are partly generated for so called "take away" food, which was subject to $15 \%$. Therefore, the more precise calculation of the VAT revenues in 2015 would require the knowledge of the share of "take away" food on total restaurant sales to compute the WAVR correctly. Because this information is not available to us, we work with the simplified WAVR for 2015 equal to $21 \%$.

Secondly, we used total final consumption in the supply and use tables that comprise exports for our estimate. Normally, exports are exempt from VAT and they should not be taken into account when calculating theoretical VAT liability. However, the inclusion of exports was intentional since exports of restaurant services represent the consumption of foreigners in Czech restaurants, which is 
also subject to Czech VAT. Thus, exports are relevant for the calculation of theoretical VAT revenues collected from restaurant businesses.

$$
A V R=\left[F C_{2017} x\left(1-\operatorname{coeff}_{i}\right) x P V P_{i} x W A V R_{2017}\right]-\left[\left(F C_{2015}-H S\right) x\left(\text { Coeff }_{2015}\right) x P V P_{2015}\right] x W A V R_{2015} \text {, }
$$

where AVR is Additional VAT Revenues, FC means Final Consumption (can be ascertained for each category of CZ- CPA individually) in purchase prices, HS is used for Hidden Sales equal to $19.56 \%$ of final consumption, which makes 24210 mil. CZK including VAT in 2015, Coeff means Coefficient for netting final consumption from VAT to get the net tax base, $\mathrm{i}=$ alternative of the share of VAT non-payers in 2017. Explanation follows in text below and Table 1., PVP stands for proportion of VAT payers (84\% in 2015 (100\% -16 \%), three alternatives in 2017) and WAVR expresses is weighted average VAT rate applicable on restaurant services, $21 \%$ in 2015 and $16.56 \%$ in 2015.

\subsection{Proportion of VAT Non-payers}

We realize that not all restaurant services for final consumption are provided by VAT payers. In order to estimate the increase in VAT revenues due to the registration of sales, we must include only the sales from VAT payers in the theoretical tax base. Therefore, it is necessary to estimate a share of VAT nonpayers on total sales in the restaurant business and exclude it from final consumption of restaurant services. This is the most questionable part of the estimate, as the proportion of sales made by the VAT non-payers is not officially known. MF (2015) reports the number of VAT non-payers in the restaurant and hotel industry divided into three categories: legal persons, individuals keeping accounts, and individuals keeping only simplified records. We calculated the share of VAT non-payers in each of those groups as follows: $51 \%$ of legal persons, $64 \%$ of individuals with double entry bookkeeping and $80 \%$ of individuals keeping simplified evidence. Unfortunately, these numbers do not provide us with the proportion of sales generated by VAT non-payers. These could be much lower, because VAT non-payers are smaller businesses. Therefore, they participate in total sales relatively less than VAT payers. The numbers of VAT non-payers are not proportional to their share on total restaurant sales.

For our calculation of potential 2017 VAT revenues generated from restaurant services final consumption, we use three alternative proportions of sales generated by VAT non-payers after the implementation of the registration of sales. The highest one assumes that the share of VAT non-payers will remain the same as before the registration of sales and is equal to $16 \%$. This number is from a survey made by the financial administration (Hrstková, 2017). This survey was made among more than 4000 restaurants randomly chosen. As a medium alternative, we use the proportion reaching $8 \%$ when considering small restaurants in villages, 
which are only open on weekends that could remain VAT non-payers. Finally, we use $0 \%$ proportion assuming that operating a restaurant with turnover less than 1 mil. CZK per year is not profitable.

\subsection{Calculation of Final Consumption Excluding VAT}

It is also important to note that final consumption in the supply and use tables is recorded in purchase prices including VAT. Therefore, we must calculate the net tax base using a coefficient that takes into account not only the VAT rate applicable on restaurant services (21\% in 2015 and combination of $15 \%$ and $21 \%$ in 2017), but also the share of VAT non-payers in the restaurant industry. This is necessary because not all final consumption was subject to VAT and CSO counts with this fact in its statistical computations of final consumption and balancing the supply and use tables. When calculating the final consumption of restaurant services in purchase prices including VAT, the CSO uses the weighted average VAT rate reflecting not only the applicable statutory VAT rates and proportion of supplies subject to these rates within the product group, but also the proportion of VAT non-payers whose sales are effectively subject to $0 \%$ rate (Hronová et al., 2009).

If there were $100 \%$ of VAT payers, the coefficient to used would be equal to 0.1736 (21/121). Considering the proportion of VAT non-payers amounting to $16 \%$ as explained above, the coefficient equals 0.1499 (in the year 2015. Since December 2016, the VAT rate for restaurant services was reduced to $15 \%$ (except for alcoholic beverages that are still subject to $21 \%$ rate). The proportion of alcoholic beverages is supposed to be $26 \%$ on sales generated by restaurants, according to information provided by the employee of the Ministry of Finance (MFCR, 2017b). Thus, the combination of rates applicable on restaurant service results in the average VAT rate of $16.56 \%$ on sales from VAT payers. For computing the net tax base from the final consumption in national accounts, we must again deduct the VAT calculated by a coefficient. This coefficient is constructed in such a manner that it takes into account the average rate $16.56 \%$ and also the estimated share of VAT non-payers in 2017. The calculation of the coefficients for determining the net tax base in 2017 for the three alternatives of the proportion of VAT non-payers is explained in more detail (using ancillary abbreviations/letters for interim calculations) in Table 1 below. 
Zídková, H. - Tepperová, J.: How Effective is Registration of Sales?

Tab. 1: Coefficients for determining the net tax base from final consumption of restaurant services

\begin{tabular}{|c|c|c|c|c|}
\hline Type of coefficient/rate & 2015 & 2017 & 2017 & 2017 \\
\hline Proportion of VAT non-payers $-\mathrm{A}=(1-\mathrm{PVP})$ & 0.16 & 0 & 0.08 & 0.16 \\
\hline Proportion of alcohol - B & & 0.26 & 0.26 & 0.26 \\
\hline VAT rate on alcohol $-\mathrm{C}$ & 0.21 & 0.21 & 0.21 & 0.21 \\
\hline VAT rate on restaurant services - D & 0.21 & 0.15 & 0.15 & 0.15 \\
\hline $\begin{array}{l}\text { WAVR on supplies from VAT payers } \\
\text { WAVRVP = C x B + D x (1- B) }\end{array}$ & 0.21 & 0.1656 & 0.1656 & 0.1656 \\
\hline $\begin{array}{l}\text { WAVR on final consumption (including that } \\
\text { from VAT non-payers) }\end{array}$ & 0.1764 & 0.1656 & 0.1524 & 0.1391 \\
\hline \multicolumn{5}{|l|}{ WAVR $=(1-A) \times$ WAVRVP $+A \times 0$} \\
\hline $\begin{array}{l}\text { Coefficient for determining the net tax base } \\
\text { Coeff. = WAVR/(1+WAVR })\end{array}$ & 0.1499 & 0.1421 & 0.1322 & 0.1221 \\
\hline
\end{tabular}

Source: Hrstková, 2017, VAT legislation, own calculation.

If there are only VAT payers in the restaurant industry, the coefficient would equal 0.1421 . If the share of VAT non-payers reaches $8 \%$, the coefficient for netting the final consumption from VAT would be 0.1322 and with the proportion of VAT non-payers at the level of $16 \%$, the coefficient would be 0.1221 .

The GDP growth in 2016 and 2017 should also be considered the estimate of total VAT revenues in 2017. However, we want to compute only the additional VAT revenues collected due to registration of sales and not due to the increase in final consumption resulting from the GDP growth. Therefore, we do not consider the GDP growth in our calculation.

\section{Results and Discussion}

Using Formula 1, we calculated potential additional VAT revenues resulting from the registration of sales in three alternatives. Each alternative corresponds to certain estimate of sales generated by VAT payers as explained above. 
Tab. 2: Estimated additional VAT annual revenues from restaurant services due to the registration of sales in 2017 in mil. CZK

\begin{tabular}{|c|c|c|c|c|}
\hline Calculation steps & 2015 & 2017 (I.) & 2017 (II.) & 2017 (III.) \\
\hline Share of VAT non-payers $-\mathrm{A}=(1-\mathrm{PVP})$ & 0.16 & 0 & 0.08 & 0.16 \\
\hline Relative hidden sales in $\%$ - RHS & 19.56 & 0 & 0 & 0 \\
\hline Final consumption - FC & 147983 & 147983 & 147983 & 147983 \\
\hline Final consumption net of hidden sales FC-HS & 123773 & 147983 & 147983 & 147983 \\
\hline Hidden sales $-\mathrm{HS}=\mathrm{FC} \times(19.56 / 119.56)$ & 24210 & 0 & 0 & 0 \\
\hline Coefficient for VAT rate - Coeff. & 0.1499 & 0.1421 & 0.1322 & 0.1221 \\
\hline $\begin{array}{l}\text { Net final consumption in national accounts - } \\
\mathrm{NFC}=(\text { FC-HC }) \times(1 \text {-Coeff. })\end{array}$ & 105213 & 126959 & 128418 & 129912 \\
\hline $\begin{array}{l}\text { Net final consumption generated by VAT } \\
\text { payers }- \text { NFCVP = NFC } x(1-A)\end{array}$ & 88379 & 126959 & 118145 & 109126 \\
\hline $\begin{array}{l}\text { (Potential) VAT revenues }- \text { VR2015; PVR = } \\
\text { NFCVP x WAVRVP }\end{array}$ & 18560 & 21024 & 19565 & 18071 \\
\hline $\begin{array}{l}\text { Additional VAT revenues }-\mathrm{AVR}=\mathrm{PVR}- \\
\text { VR2015 }\end{array}$ & & 2465 & 1005 & -488 \\
\hline
\end{tabular}

Source: National Accounts, own calculation

The VAT revenues can be increased by approx. 2.5 bill. CZK in the case when all restaurants become VAT payers or by approximately 1 bill. CZK if only $8 \%$ of restaurants remain VAT non-payers. If the proportion of VAT non-payers does not change after the registration of sales, the VAT revenues would decrease by 0.45 bill. CZK due to the reduction of the tax rate.

If we compare these results to the estimates made by the Ministry of Finance in its regulatory impact assessment report ("RIA" report) published together with the legislation that implemented the registration of sales (MFCR, 2015), we can see that our results are higher for the two scenarios where the number of VAT payers increases. However, if the share of VAT payers in restaurant industry remains the same in 2017, the increase of reported sales and VAT they paid for would not balance the decrease in the VAT rate. Thus, total VAT collection would be lower than before the registration of sales (disregarding the positive influence of the GDP growth). The estimates of the RIA report were around 0.8 bill CZK of additional VAT revenues from restaurant and hotel industry.

The RIA methodology is rather questionable. In the beginning of the report (on page 2), the authors mention that, according to tax return data, the VAT collected from VAT payers in the restaurant industry was 1.6 billion. Whereas, the theoretical VAT liability calculated from the final consumption of restaurant services in national accounts would be 11 billion CZK. Because of this, the 
authors infer that the tax evasion in the restaurant field amounts to 9.4 billion CZK. Further in their document, they come to a 0.8 bill CZK increase of VAT revenues to be achieved by registration of sales. Their conclusion about tax evasion in the restaurant industry reaching 9.4 bill CZK is incorrect. The theoretical VAT calculated from final consumption of restaurant services includes also the VAT paid on previous stages of the distribution chain, i.e. by the agriculture, food processing industry, wholesalers of food staff and other suppliers of restaurants. All these suppliers collect part of the VAT attributable to final consumption of restaurant services. Therefore, the VAT reported and paid by those suppliers is assigned to another industry (under different NACE code) when the data are taken from tax returns.

The RIA report employs three different methodologies to estimate the additional VAT revenues of the registration of sales. One is based on the Croatian results achieved from their registration of sales. Analysts of the Ministry of Finance used the increase in revenue recovery by Croatian public budgets and did some adjustments for the Czech Republic. These adjustments were, however, not closely explained. The second method of calculation was based on the shadow economy estimates. The third method mentioned in the RIA report used the information on the VAT gap for the calculation of additional VAT revenues. For more details on those methods see MF CR (2015) and for their constructive criticism see Zídková, Tepperová (2016).

We also reviewed a document provided by the Ministry of Finance per the Act on Free Access to Information on 20th September 2016 (MFCR, 2016) where the first methodology of the estimate produced by the Ministry in the RIA report was explained in more detail. The calculation is based on the estimated increase of sales in restaurant industry by 16 bill. CZK and the VAT revenues are then calculated from the margin of these sales amounting to $35 \%$ (i.e. 5.6 bill. CZK). The effective rate used by the Ministry is $18.83 \%$. Their resulting estimate is then 1.1 bill. CZK of VAT revenues in restaurant services, which is only slightly different from the RIA report. However, the calculation does not take into account the proportion of VAT non-payers. From our analysis, it is clear that the proportion of VAT payers in the industry is crucial for the extra VAT revenues that would be obtained by financial administration. Therefore, omitting these prerequisites from the analysis could cause a significant bias in the estimates.

The latest numbers from the VAT returns published by the Ministry of Finance on Internet (MFCR, 2017a) suggest the increase in restaurant sales by $83 \%$ in December 2016 (19.8 bill. CZK) compared to the sales reported in December 2015 (10.8 bill. CZK). This would indicate even higher increase in VAT collection than estimated by our methodology using data in the national accounts. This difference is likely caused by using the share of hidden sales estimated by the CSO at the 
level of approx. 20\%. The hidden sales could in reality be much higher, but they are difficult to assess.

\section{Conclusions}

The real effects of the registration of sales are eagerly awaited, since the whole project has been faced with high controversy by the public. Original estimates provided before the implementation of the registration of sales are being adjusted. It might seem that the former estimates are no longer of any use as the real "hard" data are to be known. However, it is very important to discuss the differences and accuracy of former estimates, as it can provide valuable input for improvement of similar estimates in future. It should be of great interest of the law proposers, as well as researchers to take part in the discussion of the methodology used for the calculation of future tax revenues caused by the changes in tax legislation.

Although this paper was focused on the prediction of additional VAT revenues, they are not the only ones affected by the registration of sales. Further revenues are also assumed in income taxes and obligatory insurance contributions, as it will no longer be possible to conceal the income for taxation by personal income tax and contribution. It will take even longer time to evaluate the effects for income taxes and contributions, as the tax returns are filed annually in this case.

Final effects, however, also depend on possible amendments and exemptions from the registration of sales that are still being discussed.

Regardless of the estimates, the registration of sales is a significant measure in the fight against the tax evasion since the amount of cash payments in the Czech Republic is very high.

At the same time, the registration of sales is not the cure for all the tax evasion, as it has no effect e.g. on the profit shifting of corporations in corporate income tax or carousel frauds in VAT. Thus, further measures must be taken to address other tax evasion channels. However, these must be coordinated with respect to steps taken by other countries, as they are not purely national. 
Zídková, H. - Tepperová, J.: How Effective is Registration of Sales?

\section{References}

Allingham, M., Sandmo, A., 1972. Income Tax evasion: A Theoretical Analysis. Journal of Public Economics 1, 323-338. DOI: 10.1016/0047-2727(72)90010-2.

Alm, J., Martínez-Vázquez, J., Torgler, B., 2006. Russian Attitudes Toward Paying Taxes - Before, During, and After the Transition, International Journal of Social Economics 12, 832-857. DOI: 10.1108/03068290610714670.

Bird, R. M., Martinez-Vasquez, J., Torgler, B., 2004. Societal Institutions and Tax Effort in Developing Countries, SSRN eLibrary. DOI: 10.2139/ssrn.662081

Czech Statistical Office, 2012. Revision of National Accounts, Estimates of deliberate adjusting the revenues N6. Available from: <https://apl.czso.cz/ nufile/MLR_N6_umysl_zkresl.pdf>. [10 July 2017].

ČTK, 2017. Tisíc lidí protestovalo v Praze proti EET a vládě. Na demonstraci promluvil i Václav Klaus mladší, 25 January 2017. Available from: $<$ https://zpravy.aktualne.cz/domaci/tisic-lidi-protestovalo-v-praze-proti-eet-avlade-na-demonst/r aca03584fb5611e68af8002590604f2e/>. [10 April 2017].

Daude, C., Gutiérrez, H., Melguizo, A., 2013. What Drives Tax Morale? A Focus on Emerging Economies, Hacienda Publica Espanola 4, 9-40. DOI: 10.7866/hperpe.13.4.1.

ESA, 2010. European system of national and regional accounts. Available from: <http://eur-lex.europa.eu/legal-content/CS/TXT/HTML/?uri=CELEX:32013R054 9\&from=EN>. [10 April 2017].

Financial administration, 2017a. Elektronická evidence tržeb plní očekávání: Finanční správa registruje $100 \%$ zvýšení tržeb. Available from: $<$ http://www.etrzby.cz/cs/tiskove-zpravy_EET-plni-ocekavani-FS-registrujestoprocentni-zvyseni-trzeb>. [10 April 2017].

Financial administration, 2017b. Odstartovala druhá fáze EET. Autentizační údaje si vyzvedlo 114 tisíc obchodníků. Available from: <http://www.etrzby.cz/cs/ tiskove-zpravy_Odstartovala-druha-faze-EET-Autentizacni-udaje-si-vyzvedlo114000-obchodniku>. [10 April 2017].

Frey, B. S., 2003. Deterrence and tax morale in the European Union. European Review 3, 385-406. DOI: 10.1017/s1062798703000346.

Gaviria, A., 2008. Social Mobility and Preferences for Redistribution in Latin America, Economía 1, 55-88. DOI: 10.1353/eco.2008.0003.

Hofmann, E., Hoelzl E., Kirchler. E, 2008. Preconditions of voluntary tax compliance: Knowledge and evaluation of taxation, norms, fairness, and motivation to cooperate. Journal of Psychology 216, 209-217. 
Hronová, S., Fischer, J., Hindles, R., Sixta, J., 2009. Národní účetnictví: Nástroj popisu globální ekonomiky, C.H. Beck, Praha.

Hrstková, J., 2017. EET: Nejvíc podvádějí ti největší, Hospodářské noviny (8.2. 2017), Available from: <http://nazory.ihned.cz/komentare/c1-65617390-eetnejvic-podvadeji-ti-nejvetsi>. [10 April 2017].

Hug, S., Sporri, F., 2011, Referendums, Trust, and Tax Evasion, European Journal of Political Economy 1: 120-131. DOI: 10.1016/j.ejpoleco.2010.06.005.

Kovanda, L., 2015a. Proč nesouhlasím s elektronickou evidencí tržeb. Available from: <http://roklen24.cz/a/ih5My/proc-nesouhlasim-s-elektronickou-evidencitrzeb>. [10 April 2017].

Kovanda, L., 2015b. Proč ted' už vůbec nesouhlasím s elektronickou evidencí tržeb. Available from: <http://www.penize.cz/dph/302327-lukas-kovanda-procted-uz-vubec-nesouhlasim-s-elektronickou-evidenci-trzeb>. [10 April 2017].

MFČR, 2015. Závěrečná zpráva hodnocení dopadů regulace (RIA). Návrh zákona o elektronické evidenci tržeb. Available from: <http://www.etrzby.cz/assets/ cs/prilohy/RIA.pdf>. [10 April 2017].

MFČR, 2016. Provision of Information according to $\S 14$ of the Act no. 106/1999 Coll. On Free Access to Information. Methodology of the impact calculation of the Registration of sales. No.:MF-30553/2016/10-4/1750 IK. Available from: $<$ https://www.google.cz/\#safe=active \&q=MF-30553\%2F2016\%2F10-4\%2F17 50\&*>. [10 April 2017].

MFČR, 2017a. Čísla Finanční správy o růstu tržeb se oproti číslům ČSÚ liší, není to překvapivé. Available from: <http://www.financnisprava.cz/cs/financnisprava/novinky/2017/cisla-financni-spravy-o-rustu-trzeb-se-o-7871>. [10 April 2017].

MFČR, 2017b. Information provided by email from $6^{\text {th }}$ December 2016.

OECD, 2017. Technology Tools to Tackle Tax Evasion and Tax Fraud. Available from: <http://www.oecd.org/tax/crime/technology-tools-to-tackle-tax-evasionand-tax-fraud.htm>. [10 April 2017].

Schneider, F., Buehn, A., 2007. Shadow Economies and Corruption All Over the World: Revised Estimates for 120 Countries. open-Access E-Journal, 2007-9. DOI: 10.5018/economics-ejournal.ja.2007-9.

Schneider, F., 2015. Size and Development of the Shadow Economy of 31 European and 5 other OECD Countries from 2003 to 2015: Different Developments. Available from: <http://www.econ.jku.at/members/Schneider/files/ publications/2015/ShadEcEurope31.pdf>. [10 April 2017]. 
Tait, Alan A., 1988. Value Added Tax: International Practice and Problems International Monetary Fund. Journal of Public Policy 02, 223. DOI: 10.1017/s0143814x00008151.

Torgler, B., 2012. Tax morale, Eastern Europe and European enlargement, Communist and Post-Communist Studies 1-2, 11-25. DOI: 10.1016/j.postcomstud.2012.02.005.

Ťopek M., 2017. Prodává desítky let, s počítačem neumí, tak zavře. Venkovské koloniály mizí, EET je ranou $\mathrm{z}$ milosti. 2 March 2017. Available from: $<$ https://zpravy.aktualne.cz/domaci/prodava-desitky-let-s-pocitacem-neumi-takzavre-venkovske-ko/r a19ad520ff5411e6bc0e002590604f2e/>. [10 April 2017].

Tot, A., Detelj, K., 2014. Implementation of Cash Transaction Fiscalization Procedure in Businesses: Case of Croatia. Central European Conference on Information and Inteligent Systems, September 2014.

Zídková, H., Tepperová, J., 2017. Registration of Sales. How to Measure Its Impact on Tax Revenues? In Matějová, L. (ed.). Proceedings of the 21st International Conference Current Trends in Public Sector Research, Masaryk University, Brno, 2017, 231-239. 